\title{
Research on the Training Reform of Logistics Management Professionals under the Belt and Road
}

\author{
Pan Deng \\ Logistics Management Institute, Hunan Vocational College of Modern Logistics, Changsha 410001, China \\ 49849977@qq.com
}

Keywords: the Belt and Road; Logistics Management Major; comprehensive quality

\begin{abstract}
The proposal of the Belt and Road Initiative has put forward new requirements for talents in China's logistics management profession. This paper briefly introduces the Belt and Road Initiative and analyzes the impact of this initiative on the training program for logistics management professionals. Therefore, this paper puts forward a series of suggestions for the cultivation of talents from four aspects: language ability, professional skill, practical ability and competitive consciousness. The aim is to lay a foundation for the improvement of the comprehensive quality of modern logistics management professionals and the enhancement of our country's comprehensive strength.
\end{abstract}

\section{Introduction}

In order to promote the common economic progress of other countries on the basis of developing its own economy, China proposed the Belt and Road Initiative on March 28, 2015. As a major related to international trade, the training mode of traditional talents in logistics management has been greatly impacted. Today, as the international economic and trade situation is changing, it has become an important direction for the teaching reform of logistics management to actively reform the training mode of talents and improve the adaptability of talents and the needs of the times.

\section{The Training Reform of Logistics Management Professionals under the Belt and Road}

\subsection{Reform on Language and Competition Awareness Training}

The Belt and Road, also known as the "21st Century Maritime Silk Road", is a trade road proposed by China, benefiting many countries and regions, such as Russia, Poland and so on. The number of countries covered by the Belt and Road Initiative is shown in Table 1:

Table 1 The Number of Countries Covered by the Belt and Road Initiative

\begin{tabular}{cccccc}
\hline Country & $\begin{array}{c}\text { ASEAN and } \\
\text { South Asia }\end{array}$ & $\begin{array}{c}\text { Western and } \\
\text { Central Asia }\end{array}$ & CIS & CE+EE & WE+America \\
Quantity & 20 & 23 & 7 & 16 & 0 \\
\hline
\end{tabular}

Under the above background, in order to be able to communicate with other countries, the logistics management profession must strengthen the cultivation of talents' language ability and competition awareness and improve their overall quality.

\subsection{Reform on Professional and Practical Ability Training}

The proposal of the Belt and Road Initiative has not only improved China's export volume, but also increased the foreign trade volume of other countries, bringing about a greater impetus for the development of all countries. In 2017, China's exports to countries along the Belt and Road are shown in Table 2: 
Table 2 China's Exports to Countries along the Belt and Road in 2017

\begin{tabular}{clccc}
\hline Country & Russia & Vietnam & Kazakhstan & Poland \\
\hline $\begin{array}{c}\text { Export value (hundred } \\
\text { million U.S. dollars) }\end{array}$ & 75.28 & 28.36 & 20.02 & 13.58 \\
\hline
\end{tabular}

It can be seen that the proposal of the Belt and Road Initiative has increased the volume of foreign trade, and at the same time it has increased China's contact with other countries. In this context, the community's requirements for professionalism and practical ability of logistics management professionals have increased significantly. Strengthening teaching reform is in haste.

\section{The Training Scheme of Logistics Management Professionals under the Belt and Road}

This section studies the training program for logistics management professionals in the context of the Belt and Road Initiative from the aspects of language ability and competitive consciousness, etc.:

\subsection{Language Proficiency Training Program}

The proposal of the Belt and Road Initiative has gradually extended the logistics to the world. In order to improve the comprehensive quality of talents, the major of logistics management should increase the proportion of language courses to promote the employment of talents. A university has adjusted the proportion of business English, international trade and logistics management in teaching, and achieved good results. Specific adjustments are proposed in Table 3:

Table 3 Training Courses for Logistics Management Professionals

\begin{tabular}{cccccc}
\hline $\begin{array}{c}\text { Major } \\
\text { Courses }\end{array}$ & $\begin{array}{c}\text { Business } \\
\text { English }\end{array}$ & $\begin{array}{c}\text { International } \\
\text { Trade }\end{array}$ & $\begin{array}{c}\text { Logistics } \\
\text { Management }\end{array}$ & $\begin{array}{c}\text { Supply } \\
\text { Chain } \\
\text { Management }\end{array}$ & $\begin{array}{c}\text { International } \\
\text { Logistics }\end{array}$ \\
\hline Department & 150 & 78 & 85 & 78 & 78 \\
\hline
\end{tabular}

The rationality of the proportion of each course can be effectively improved by adopting the above method to design the curriculum. On the basis of improving the professional quality of talents, the language ability can be improved.

\subsection{Competition Awareness Training Program}

Under the background of Belt and Road, logistics management professionals should improve their own competitive consciousness in order to meet the needs of the society. Therefore, the teaching mode of cooperation between school and enterprise can be applied to the process of talent training. Students are required to practice in enterprises before graduation, so that their own sense of competition can be enhanced. A survey of students' competitive consciousness before and after the use of the university-enterprise model in a certain university is shown in Table 4:

Table 4 The Competitive Consciousness of the Students before and after the Use of the University-Enterprise Model in a University

\begin{tabular}{cccc}
\hline Item & Number of students & Pre-alliance & Post-alliance \\
\hline Data & 105 & 26 & 100 \\
\hline
\end{tabular}

The results show that the application of school-enterprise association model makes students understand the importance of competition, which will play a certain role in promoting the improvement of students' basic skills.

\subsection{Professional Skills Development Program}

The propose of Belt and Road Initiative has raised the requirements for professional skills of logistics management professionals. At present, various software represented by ERP has been 
widely applied to enterprises. The survey shows that the ERP software penetration rate of domestic logistics management companies is shown in Table 5:

Table 5 Popularization of ERP Software in Domestic Logistics Management Enterprises

\begin{tabular}{cccc}
\hline Item & $\begin{array}{c}\text { Number of } \\
\text { enterprises }\end{array}$ & $\begin{array}{c}\text { Software application } \\
\text { number }(\mathrm{n})\end{array}$ & $\begin{array}{c}\text { Software application } \\
\text { rate (\%) }\end{array}$ \\
\hline Data & 101 & 98 & 97.03 \\
\hline
\end{tabular}

In order to make the quality of talents and meet employment needs, colleges and universities can apply ERP software to the process of cultivating talents. Through simulation experiments, students can fully grasp the application methods of ERP software, and make its quality can accord with Belt and Road's proposal, strengthen the basic ability of talented person.

\subsection{Practical Ability Development Program}

The application of simulation training in the process of training logistics professionals can effectively improve the students' mastery of supply chain knowledge and further meet the demand for talents in China's trade development under the background of the Belt and Road. A certain university in our country applied the simulation experiment platform to the teaching process and provided opportunities for students to observe the operation flow of the supply chain. Through the observation of the students' final grades, it is found that the students' scores (100 points system) are obviously improved after the application of the platform. See Table 6 specifically:

Table 6 Students' Achievement before and after Application Simulation Experiment Platform in a University

\begin{tabular}{cccc}
\hline Item & Number of students & $\begin{array}{c}\text { Pre-application of } \\
\text { platform (point) }\end{array}$ & $\begin{array}{c}\text { Post-application of } \\
\text { platform (point) }\end{array}$ \\
\hline Data & 284 & 84.59 & 96.52 \\
\hline
\end{tabular}

\section{Conclusion}

In summary, the proposal of the Belt and Road Initiative not only provided the impetus for the reform of logistics professional training, but also brought challenges to it. Under the background of the Belt and Road, in order to train applied talents, our country's logistics management major should strengthen the cultivation of talents' language ability and improve their communication ability with other countries. It is necessary to cultivate the professional skills and practical ability of talents, and improve the mastery of informationized logistics knowledge. On this basis, actively cultivate the competitive awareness of talent, so that its comprehensive quality, can get a greater degree of improvement.

\section{References}

[1] Li K X, Jin M, Qi G, et al. Logistics as a driving force for development under the Belt and Road Initiative - the Chinese model for developing countries[J]. Transport Reviews, 2017(2):1-22.

[2] Chinsinga B. The Green Belt Initiative, Politics and Sugar Production in Malawi[J]. Journal of Southern African Studies, 2016:1-15.

[3] Lau Y, Tam K, Ng A K Y, et al. Effects of the 'Belt and Road' initiative on the wine import logistics of China[J]. Maritime Policy \& Management, 2017(4):1-15.

[4] Lee T W, Hu Z H, Lee S J, et al. Research trends and agenda on the Belt and Road (B\&R) initiative with a focus on maritime transport[J]. Maritime Policy \& Management, 2017(2):1-19.

[5] Chhetri P, Nkhoma M, Peszynski K, et al. Global logistics city concept: a cluster-led strategy under the belt and road initiative[J]. Maritime Policy \& Management, 2017(3):1-17. 